\title{
The complete chloroplast genome of Microcycas calocoma (Miq.) A. DC. (Zamiaceae, Cycadales) and evolution in Cycadales
}

\author{
Aimee Caye G. Chang ${ }^{1,2,3}$, Qiang Lai ${ }^{1}$, Tao Chen ${ }^{2}$, Tieyao Tu ${ }^{1}$, Yunhua Wang ${ }^{2}$, Esperanza Maribel G. Agoo ${ }^{4}$, Jun \\ Duan Corresp., 1 , Nan Li ${ }^{\text {Corresp. } 2}$ \\ ${ }^{1}$ South China Botanical Garden, Chinese Academy of Sciences, Guangzhou, China \\ 2 Shenzhen Fairy Lake Botanical Garden, Chinese Academy of Sciences, Shenzhen, China \\ 3 University of Chinese Academy of Sciences, Beijing, China \\ 4 Department of Biology, De La Salle University, Manila, Philippines \\ Corresponding Authors: Jun Duan, Nan Li \\ Email address: duanj@scib.ac.cn, andreali1997@126.com
}

Cycadales is an extant group of seed plants occurring in subtropical and tropical regions comprising putatively three families and ten genera. At least one complete plastid genome sequence has been reported for all of the ten genera except Microcycas, making it an ideal plant group to conduct comprehensive plastome comparisons at the genus level. This paper reports for the first time the plastid genome of Microcycas calocoma. The plastid genome has a length of 165,688 bp with 134 annotated genes including 86 protein-coding genes, 47 non-coding RNA genes (39 tRNA and 8 rRNA) and one pseudogene. Using global sequence variation analysis, the results showed that all cycad genomes share highly similar genomic profiles indicating significant slow evolution and little variation. However, identity matrices coinciding with the inverted repeat regions showed fewer similarities indicating that higher polymorphic events occur at those sites. Conserved non-coding regions also appear to be more divergent whereas variations in the exons were less discernible indicating that the latter comprises more conserved sequences. Phylogenetic analysis using 81 concatenated protein-coding genes of chloroplast (cp) genomes, obtained using maximum likelihood and Bayesian inference with high support values ( $>70 \% \mathrm{ML}$ and $=1.0 \mathrm{BPP}$ ), confirms that Microcycas is closest to Zamia and forms a monophyletic clade with Ceratozamia and Stangeria. While Stangeria joined the Neotropical cycads Ceratozamia, Zamia and Microcyas, Bowenia grouped with the Southern Hemisphere cycads Encephalartos, Lepidozamia and Macrozamia. All Cycas species formed a distinct clade separated from the other genera. Dioon, on the other hand, was outlying from the rest of Zamiaceae encompassing two major clades - the Southern Hemisphere cycads and the Neotropical cycads. Analysis of the whole cp genomes in phylogenv also sunports that the nreviously recognized family - Stangeriaceae - which
peerpreviewing PDF (2019:09:40891:2:1: NEW 20 Nov 2019) 
contained Bowenia and Stangeria, is not monophyletic. Thus, the $\mathrm{cp}$ genome topology obtained in our study is congruent with other molecular phylogenies recognizing only a two-family classification (Cycadaceae and Zamiaceae) within extant Cycadales. 


\title{
The Complete Chloroplast Genome of Microcycas calocoma (Miq.) A. DC. (Zamiaceae, Cycadales) and Evolution in Cycadales
}

\author{
Aimee Caye G. Chang, ${ }^{1,2,3 *}$, Qiang Lai ${ }^{1,3}$, Tao Chen ${ }^{2}$, Tie-Yao Tu${ }^{1}$, Yun-Hua Wang ${ }^{2}$, Esperanza \\ Maribel Agoo ${ }^{4}$, Jun Duan ${ }^{1, *}$, Nan $\mathrm{Li}^{2}$,* \\ ${ }^{1}$ South China Botanical Garden, Chinese Academy of Sciences, Guangzhou, China \\ ${ }^{2}$ Shenzhen Fairy Lake Botanical Garden, Chinese Academy of Sciences, Shenzhen, China \\ ${ }^{3}$ University of Chinese Academy of Sciences, Beijing, China \\ ${ }^{4}$ Department of Biology, De La Salle University, Manila, Philippines \\ * Correspondence: \\ Jun Duan Nan Li \\ duanj@scib.ac.cn $\quad$ andreali1997@,126.com
}

Keywords: Microcycas, Zamiaceae, Cycadales, cpDNA, chloroplast genomes, phylogeny, plastids, cycads, evolution 
67

68

69

70

71

72

73

\section{INTRODUCTION}

Chloroplasts are essential organelles for photosynthesis in plant tissues. Their primary function is to fix carbon by harnessing solar energy to synthesize carbohydrates, pigments and amino acids (Hong et al., 2017; Liu et al., 2017). These plant organelles, alongside mitochondria, contain their own DNA and a unique set of genes and are also referred to as plastomes (Wu \& Chaw, 2015) although the bulk of gene content is in the nucleus of most eukaryotic organisms (Lodish et al., 2000). Generally, the chloroplast (cp) genome consists of a large single copy (LSC) region and a small single copy (SSC) region located directly across from each other. Between these two regions are two inverted repeat (IR) sequences $\left(\mathrm{IR}_{\mathrm{A}}\right.$ and $\left.I R_{B}\right)$. These four regions make up a single quadripartite circular structure about 120-160 kb in length (Liu et al., 2017; Lee et al., 2006). However, some reports and more recent data from over 1500 complete genome sequences of chloroplasts from land plants showed that their size ranged up to $170 \mathrm{~kb}$ (Smith, 2017; Shaw, 2007).

Chloroplast genomes prove to be advantageous over nuclear genomes in ease of handling and analyzing due to their reduced complexity in structure and dimensions. Despite the relatively smaller genome size, a large amount of data can be obtained using cp genomes such as nucleotide substitutions, pseudogenes, intron losses and variation in genome size. Compared to nuclear and mitochondrial DNA, cp genomic regions are more stable and conserved due to their maternal lineage (Zhong et al., 2011) and lack of recombination events (Martin et al., 2005). Information gathered from cp genome sequences are also extensively used in addressing uncertainties in evolutionary relationships in various taxa, reconstructing phylogenetic relationships, and gaining a deeper understanding of biogeographical, structural and functional diversity across all organisms (Jiang et al., 2016). These features of chloroplast or plastid DNA (cpDNA or ptDNA) make them ideal models for genome-wide evolutionary studies (Asaf et al., 2016; Choi et al., 2016; Jiang et al., 2016).

Cycads (Cycadophyta) are one particular plant group where studies of molecular phylogeny have been broadly applied (Liu et al., 2018; Gorelick et al., 2014; Lu et al., 2014; Salas-Leiva et al., 2013; Chaw et al., 2005; Hill et al., 2003). Because of their ancestry and close morphological resemblance to some pteridophytes and angiosperms (Xiao and Moller, 2015), cycads belong to the earliest lineage among the five major groups of seed plants (Cycadales, Coniferales, Ginkgoales, Gnetales; and angiosperms) that date back as far as the Carboniferous Period about $300 \mathrm{Ma}$ (Jiang et al., 2016; Wu and Chaw, 2015, Wu et al., 2007). Evidences were plant fossils discovered from late Permian determined to be morphologically-related to extant cycads (Gao et al. 1989). However, Nagalingum et al. (2011) considered that species diversification in cycads occurred recently by analyzing PHYTOCHROME P (PHYP) nuclear gene, in which it showed that the age of extant cycads dates back to only 12 million years. But regardless of various hypotheses, cycads as a key node in the evolutionary phylogeny of green living things remain true.

Cycads are the second largest group of gymnosperms. They comprise putatively three families, ten genera and 356 extant species (Calonje et al., 2019; Feng et al., 2017; Jiang et al., 2016). Currently, assessment on the status of cycads based on IUCN Red List reports that $19.8 \%$ are near threatened, $23.1 \%$ are vulnerable, $20.4 \%$ are endangered, $17.3 \%$ are critically endangered and $1.2 \%$ are already extinct in the wild (The IUCN Red List of Threatened Species, 2019). Owing to their aesthetic nature, cycads are significant in horticulture (Jiang et al., 2016; Wu and Chaw, 2015). 
Unfortunately, exploitation for personal and ornamental use, their slow reproductive rate and habitat destruction have resulted in significant declines in cycad populations and poses a threat to the longevity of the plants and to seed production (Pinares et al., 2009; Stevenson et al., 2003). One species currently on the verge of extinction is Microcycas calocoma (Miq.) A.DC., a species endemic to western Cuba (north to central of Pinar del Rio Province). It grows in montane forests and on limestone in lowlands and grasslands between 50 and 250 meters and is currently listed as critically endangered (The IUCN Red List of Threatened Species, 2019; Bösenberg, 2010). At present, the monotypic M. calocoma is represented by less than 1000 individuals worldwide. It was previously reported that the female cones are becoming non-receptive to fertilization causing failure in producing viable seeds (Whitelock, 2002). However, this claim still requires research for evidences and validation. Most probable factor to unsuccessful fertilization might be due to the limited cycad-pollinator interactions. Pharaxonotha is a taxon of beetles known to pollinate New World Zamiaceae such as Zamia, Dioon and Ceratozamia, wherein the species $P$. esperanzae was first described in Cuba as potential pollinator of $M$. calocoma found breeding in male cones and feeds on pollen (Chaves and Genaro, 2005). According to Chaves and Genaro (2005), this discovery paves a way to investigate factors that influence natural reproduction in Microcycas that could also address why some populations fail to reproduce. Other threats commonly encountered by cycads species could be factors induced by humans (e.g. intentional private use, over-collection, habitat destruction, grazing, fire, etc.), by climate (e.g. drought, floods, etc.) and by pressures linked to the biology of cycads some of which were already mentioned above such as reproductive failure, dispersal ability and limited number of identified pollinators to facilitate conservation, among others (The IUCN Red List of Threatened Species, 2019; Mankga and Yessoufou, 2017; Chaves and Genaro, 2005).

Of the ten accepted genera in Cycadales, only Microcycas lacks a completely sequenced chloroplast genome. This study therefore aimed to determine for the first time the whole chloroplast genome of Microcycas calocoma to elucidate the variation and evolution in chloroplast genomes in Cycadales.

\section{MATERIALS AND METHODS \\ DNA extraction, library preparation and sequencing}

Five grams of fresh leaves of Microcycas calocoma was collected from a plant cultivated in the China National Cycad Conservation Center at Shenzhen Fairy Lake Botanical Garden (Chen T. 2017011701, SZG) for cpDNA isolation using a modified extraction method of McPherson et al. (2013). After DNA isolation, $1 \mu \mathrm{g}$ of purified DNA was fragmented to build short-insert libraries with an insert size of $350 \mathrm{bp}$ following the manufacturer's instructions (Illumina). The short fragments were then sequenced using an Illumina Hiseq 4000 sequencing system at Total Genomics Solution (TGS) in Shenzhen, China (Borgstrom et al., 2011).

\section{Genome assembly}

Approximately $1,538 \mathrm{Mb}$ of raw reads with an average read length of $140 \mathrm{bp}$ was generated from paired-end sequencing. Raw sequence reads were then filtered prior to genome assembly to remove adaptors sequences and 1,244 $\mathrm{Mb}$ of cleaned data was used to obtain 165,688bp assembled chloroplast genome. The cp genome of Microcycas was reconstructed by combining de novo and reference-guided assemblies (Cronn et al., 2008). The following steps were performed: (1) clean 
132 sequence reads were assembled into contigs using SOAPdenovo v2.04 (Li et al., 2010) 133 (http://soap.genomics.org.cn/soapdenovo.html) short sequence assembly software, then the 134 assembly results were constructed and optimized according to the paired-end and overlapping 135 reads by filling the gaps and removing redundant sequence segments using GapCloser v1.12 136 (http://soap.genomics.org.cn/soapdenovo.html); (2) for additional guidance in the assembly, 137 BLAST was used to align the contigs to the reference genome Bowenia serrulata (GenBank ID: 138 NC_026036.1), which was selected for having the closest sequence length $(165,695 \mathrm{bp})$ with 139 Microcycas among available non-Cycadaceae complete chloroplast genome, then aligned contigs 140 (>80\% similarity and query coverage) were organized according to the reference genome; and (3) 141 obtained reads were mapped to the assembled draft $\mathrm{cp}$ genomes that were visualized by OrganellarGenomeDRAW v1.2 (Lohse et al., 2007).

\section{Genome annotation and sequence analysis}

Using default parameters to predict protein-coding genes, transfer RNA (tRNA) genes, and ribosome RNA (rRNA) genes, annotation of the chloroplast genes was performed using online processing tools, DOGMA (Wyman et al., 2004) and CpGAVAS software 148 (http://www.herbalgenomics.org/0506/cpgavas/analyzer/home). A whole chloroplast genome BLAST (Altschul et al., 1990) search (E-value $\leq 1 \mathrm{e}-5$, minimal alignment length percentage $\geq$ 40\%) was performed against 5 databases: KEGG (Kyoto Encyclopedia of Genes and Genomes) (Kanehisa et al., 2006; Kanehisa et al., 2004; Kanehisa, 1997), COG (Clusters of Orthologous Groups), NR (Non-Redundant Protein Database databases) (Tatusov et al., 2003; Tatusov et al., 1997), Swiss-Prot (Magrane, 2011), and GO (Gene Ontology) (Ashburner et al., 2000) to check and combine annotated genes with their amino acid sequences and corresponding functional annotation information. Finally, the circular Microcycas calocoma chloroplast genome map was drawn using OGDraw v1.2 (Lohse et al., 2007). The sequence was then deposited and can be viewed in National Center for Biotechnology Information (NCBI) database (http://www.ncbi.nlm.nih.gov/nuccore) with accession number MN577566.

\section{Sequence alignment and phylogenetic analyses}

Complete chloroplast sequences available in the NCBI database were retrieved and included in the dataset for phylogenetic analyses. All currently available sequenced whole cp genomes under Cycadales and Ginkgoales were obtained. A total of 15 sequences were included in the data set (Supplementary table S1).

Eighty-one protein-coding genes encompassing LSC, SSC and IR regions and excluding intergenic spacers were extracted from the plastid genomes followed by alignment of each gene using MAFFT multiple aligner with default parameters in Geneious Prime v2019.0.3 (https://www.geneious.com, Kearse et al., 2012). Ambiguous regions that have low nucleotide similarities causing large alignment gaps were then manually removed from some genes, after which, all aligned genes were concatenated resulting in total length of 55,971 bp prior to phylogenetic analyses. The data matrix was subjected to maximum likelihood (ML) phylogenetic reconstruction using RAxML v.8 (Stamatakis, 2014) with GTR $+\mathrm{I}+\mathrm{G}$ substitution model selected by jmodeltest 2 and 1000 bootstrap replicates. Bayesian inference (BI) was also calculated using MrBayes 3.2.6 using a GTR model of nucleotide substitution and a gamma distribution rate variation across sites (Ronquist and Huelsenbeck, 2003) setting four MCMC running for one million generations with sampling every 1,000 generations and the first $25 \%$ discarded as burn-in. 
178

179

180

181

182

183

184

185

186

187

188

189

190

191

192

193

194

195

196

197

198

199

200

201

202

203

204

205

206

207

208

209

210

211

212

213

214

215

216

217

218

219

220

221

222

223

Branches with bootstrap values $>75$ for $\mathrm{ML}$ and Bayesian posterior probabilities $>0.95$ for BI were considered as highly supported. Both ML and BI analyses were conducted in CIPRES Science Gateway (www.phylo.org) (Miller et al., 2010). Alignment of sequence identities were plotted using mVISTA online platform (Frazer et al., 2004; Mayor et al., 2000). Ten genera of Cycadales were included to analyze similarity profiles on coding and noncoding regions across the genomes. Shuffle-LAGAN alignment program was selected as a parameter prior to run the analysis (Brudno et al., 2003) as this setting performs global alignment that detects rearrangements and inversions.

\section{RESULTS \\ Plastome size and features of Microcycas calocoma}

The genome size of the complete chloroplast DNA of Microcycas calocoma is 165,688 bp in length with 86 protein-coding genes (88,778 bp), 39 tRNA genes (9,050 bp) and eight ribosomal RNA genes $(2,906 \mathrm{bp})$. In $M$. calocoma, the tufA gene contains 5 premature stop codons within the sequence therefore making it a pseudogene. One hundred and thirty three genes were organized in a circular quadripartite structure consisting of large and small single copy regions separated by two inverted repeat regions (Figure 1) composed of 90,651 bp, 22,741 bp and a pair of 26,184 bp regions, respectively. In the entire cp genome of $M$. calocoma, 4 protein-coding $(n d h \mathrm{~B}, r p s 7$, $r p s 12, y c f 2), 4$ rRNA (rrn16, rrn23, rrn4.5, rrn5) and 7 tRNA genes (trnA-UGC, $\operatorname{trnH}-\mathrm{GUG}, \operatorname{trnI}-$

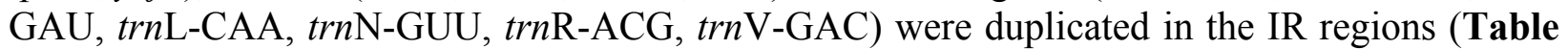
1). The protein-coding gene rps 12 was also trans-spliced in the LSC aside from being duplicated in the IRs. The presence of 2 split genes (trnK-UUU/matK and $a t p \mathrm{~B} / a t p \mathrm{E})$ in the LSC were also found. The overall GC content of $M$. calocoma (39.6) falls within the range of sequenced chloroplast genomes of cycads which range from 39.4 to $40.1 \%$. LSC, SSC and IR regions have $38.8 \%, 37.2 \%$ and $41.8 \% \mathrm{GC}$ content, respectively.

\section{Plastome features in Cycadales}

Thirteen completely-sequenced chloroplast genomes, representing nine of the ten genera of cycads, were in GenBank during our study. The addition of the plastid genome of Microcycas calocoma makes known the sequences of all genera of Cycadales. Summary of the genome features in all sequenced cp genomes of cycads was shown in (Table 2).

The smallest genome with 161,815 bp is in Dioon spinolosum while Macrozamia mountperriensis consisting of 166,341 bp has the largest. Despite significant difference in genome length, both species contain 135 genes (87 protein-coding, 39 tRNA, eight rRNA, one pseudogene) indicating that an increase in plastome size does not denote addition of genes or functions. The number of genes in cycads typically ranges from 133 to 135 except in C. revoluta and C. panzhihuaensis, both of which have 157 genes, and $C$. taitungensis which has 169 genes, the highest number in cycads. These three species of Cycas also have the highest number of protein-coding genes among cycads with 109 genes in C. revoluta and C. panzhihuaensis and 122 genes in C. taitungensis. Variation in the number of tRNAs was also observed. Cycas debaoensis has 37, C. taitungensis and Bowenia serrulata both have 38, while the remaining cycads have 39 tRNAs. In comparison, the number of ribosomal RNA (rRNA), eight, is the same in all cycads. 
224 The majority of cycads have 87 protein-coding genes and one pseudo-tufA gene. Interestingly, 225 Stangeria eriopus has 81 coding genes and six reported pseudogenes - chlL, chlN, rpl23, tufA, 226 chlB and matK genes (Wu and Chaw, 2015). Microcycas calocoma contains one tufA pseudogene 227 (ItufA) which is also in all cycad genomes. Jiang et al. (2016) reported that the ItufA gene of 228 Cycas debaoensis was one base pair longer than in C. taitungensis (723bp). In M. calocoma, this 229 pseudogene is $1,233 \mathrm{bp}$ in length.

\section{Sequence variation in cycads}

Using one representative per genus, mVISTA produced a plot showing peaks and valleys where pink regions denote conserved non-coding sequences (CNS). White regions indicate sites within the genome that are indistinctly aligned, suggesting more variable sites. These regions happen to coincide with the inverted repeat regions of all chloroplast genomes suggesting that IRs are prone to polymorphisms in comparison with the LSC and SSC regions. High degree of synteny in the coding regions was observed across all genomes of Cycadales when $C$. debaoensis was used as a base reference, as indicated by the purple-colored blocks (conserved exons) for all genomes (Figure 2). Due to the lack of other representative complete chloroplast genomes under Zamiaceae, a Cycas species was used as reference. Since a Cycas species was used as base reference, only $C$. panzhihuaensis showed an obviously unique pattern indicating that it shares more similar regions with the reference as they are more closely related, setting it apart from the identity plots of the rest of the species which all belong to Zamiaceae. Divergence in CNS regions was higher whereas variations in coding regions were less discernible. Most divergent regions were apparent in the intergenic spacers among all cp genomes. As shown in our alignment, these highly varied sites include regions between $p s b \mathrm{~A}-m a t \mathrm{~K}, p e t \mathrm{~A}-p s b \mathrm{~J}$, pet $\mathrm{L}-p s b \mathrm{E}, n d h \mathrm{~F}-c c s \mathrm{~A}$, among others. Nonetheless, these plots suggest high similarities in the nucleotide sequences within Cycadales. It also denotes that slow evolution occurs in Cycadales where gene order is highly conserved and a reduced amount of gene rearrangements occur.

\section{Phylogenetic analyses}

The phylogeny obtained from the complete chloroplast sequences of cycads using maximum likelihood (ML) and Bayesian inference (BI) revealed several consistencies from previous studies employing various gene segments from nuclear and/or chloroplast DNA (Figure 3). Both trees obtained showed significant support ( $>70$ for ML and $>0.95$ Bayesian Posterior Probability for BI) and consistency in tree topologies. These include the monophyly of the three major clades: (1) all Cycas spp., (2) the Encephalartoid clade or "Southern Hemisphere clade" consisting of Encephalartos-Lepidozamia-Macrozamia genera, and (3) the "Neotropical clade"' comprising of Ceratozamia-Microcycas-Zamia group. Moreover, Dioon was confirmed as sister to the rest of Zamiineae (Liu et al., 2018; Lu et al., 2014; Gorelick et al., 2014; Salas-Leiva et al., 2013).

Phylogenetic analyses also showed that Microcycas is closer to Zamia than to other genera of cycads which is congruent with previous studies using chloroplast matK and $r b c L$ genes, $\operatorname{trnK}$ intron, nuclear rDNA ITS gene and concatenated nuclear and plastid DNA sequences (Lu et al., 2014; Salas-Leiva et al., 2013 Chaw et al., 2005; Hill et al., 2003). Furthermore, the monogeneric Cycadaceae forms the basal-most clade wherein $C$. panzhihuaensis and the sisters $C$. taitungensis and $C$. revoluta diverged from $C$. debaoensis. The phylogenetic placements of Bowenia and 
270

271

272

273

274

275

276

277

278

279

280

281

282

283

284

285

286

287

288

289

290

291

292

293

294

295

296

297

298

299

300

301

302

303

304

305

306

307

308

309

310

311

312

Stangeria were controversial, where older references recognize that they belong to the same family Stangeriaceae (Stevenson, 1992; Stevenson, 1981). In our study, these two genera separated into different clades. Even though showing weaker ML support, Bowenia (72 ML and 1.0 BPP) grouped with the Encephalartoid clade while Stangeria, with significant support (90 ML and 1.0 BPP), was sister to Ceratozamia clustered in the Neotropical clade. As the results suggest that the African cycad Stangeria is closest to Neotropical cycads instead of its supposed closest relatives in terms of morphology (Bowenia) and biogeographic location (Encephalartos), this interesting classification will be further discussed below, as well as the placement of Bowenia with the Southern Hemisphere cycads.

\section{DISCUSSION}

\section{Plastomes of cycads}

Based on previously-completed sequences, 100-130 unique genes are contained within chloroplast genomes of cycads (Jiang et al., 2016; Wu and Chaw, 2015; Wu et al., 2007). Approximately 79 of these genes code for proteins involved in metabolic pathways for photosynthesis whereas the remaining 30 are responsible for coding transfer RNAs (tRNAs) and four are responsible for ribosomal RNAs (rRNAs) (Hong et al., 2017; Dong et al., 2013; Yang et al., 2013). In this study, the whole chloroplast genome of Microcycas calcoma was presented and 13 complete chloroplast genomes of cycads representing nine genera within Cycadales were used for comparison. Hence, all the ten genera within Cycadales now have at least one species with complete chloroplast genome.

The gene organization, content and order in cycad genomes appear to be highly conserved in all ten genera. This agrees with previous reports (Rai et al., 2003; Wu et al., 2007) and supports the slow evolution of cycads in which the changes that occur in the genomes are very minimal since they diverged in the early Jurassic (Nagalingum et al., 2011; Wu and Chaw, 2015). Our study showed that even the universal barcode loci matK and $r b c \mathrm{~L}$ are not highly variable in cycads. On the contrary, we observed that $y c f 1, y c f 2$ and $a c c \mathrm{D}$ genes are highly polymorphic sites across all cycad plastomes.

The non-functional gene, tufA, was inherited from the charophyte lineage of green algae that once coded for a functional protein elongation factor (Wu et al., 2007). Functional tufA genes are present in the cpDNA of algae and bacteria; and are also known to be transferred from the cpDNA to the nuclear ribosomal DNA (nrDNA) in rice, legumes, tobacco and Arabidopsis (Wu et al., 2007; Sugita et al., 1994; Baldauf \& Palmer, 1990). Pseudo-tufA genes are also in the genomes of Anthoceros (hornwort) and Ginkgo. In cycads, the highest frequency of pseudonized genes (6) were present in Stangeria eriopus (Wu et al., 2007).

\section{Sequence variations and evolution in Cycadales}

Sequence identity plots of cycad genomes identified highly conserved coding (purple) regions. Non-coding (pink) regions appeared more divergent whereas white areas mostly coinciding with IR regions also showed less sequence similarities. According to $\mathrm{Wu}$ and Chaw (2015), gene conversions frequently occur in IRs, which favors a GC-biased (gBGC) substitution mechanism. $\mathrm{gBGC}$ is believed to be the mechanism employed by cycads in amending plastome-wide 
313

314

315

316

317

318

319

320

321

322

323

324

325

326

327

328

329

330

331

332

333

334

335

336

337

338

339

340

341

342

343

344

345

346

347

348

349

350

351

352

353

354

355

356

357

358

mutations, therefore playing a role in evolutionary stasis and genome stability of chloroplast genomes (Wu and Chaw, 2015). The results of the global sequence alignment agreed with the phylogeny employing 81 protein-coding genes, obtained using maximum likelihood and Bayesian inference with high support values $(>70 \%$ and $=1.0 \mathrm{BPP})$. It showed that the three major clades that grouped together had common identity profiles, thus denoting close relationships. These three are the Cycas group, the Australian genus Bowenia joining the Southern Hemisphere group (Encephalartos-Lepidozamia-Macrozamia), and South African genus Stangeria joining the Neotropical group (Ceratozamia-Microcycas-Zamia). Geographical patterns and distribution of cycads coincide with our phylogenetic analyses using $\mathrm{cp}$ genomes but with few exceptions discussed in the succeeding sections such as the case of African genera Stangeria and Encephalartos which were separated into different clades.

The use of whole chloroplast genomes shows a clear delineation separating Cycadaceae from the rest of the cycads. But for Zamiaceae, numerous studies have shown that the taxonomic placement of Bowenia, Stangeria and Dioon was ambiguous and their phylogeny remains unresolved (Gorelick et al., 2014; Bogler and Francisco-Ortega, 2004). In this study, Dioon was basal among the three genera, Bowenia formed a monophyletic group with Encephalartos-LepidozamiaMacrozamia and Stangeria was sister to Ceratozamia forming a monophyletic clade with Microcycas and Zamia. This is congruent with other phylogenies wherein Dioon separated from other genera and contained two major clades (Salas-Leiva et al., 2013; Bogler and FranciscoOrtega, 2004; Hill et al., 2003). Morphological synapomorphies that can be correlated in our cpDNA topology include the presence of stomata on the sporangia of all Zamiaceae cycad species (Dehgan et al., 1993); Encephalartos, Lepidozamia and Macrozamia all have lateral lobes in the megasporophylls (Stevenson, 1990); Microcycas and Zamia have asymmetrically-branched trichomes (Stevenson, 1990); Encephalartos and Lepidozamia have a common mucilage chemistry not found in other cycads (De Luca et al., 1982); and the Australian Macrozamia and African Encephalartos both having pith structures intersected by gum canals and irregular cauline vascular bundles, in contrast to the peduncular vascular bundles found in Dioon, Stangeria, Ceratozamia and Zamia (Berry, 1918). Moreover, Stangeria and Bowenia share few similarities with some members of their respective clades such as the formation of tracheids in Stangeria and Zamia are scalariform, and the orientation of vascular bundles in the tertiary cambium of Bowenia and Macrozamia are both inverted (Govil, 2014; Berry, 1918).

Stevenson (1981) previously described a family Boweniaceae for the genus Bowenia but striking morphological similarities eventually unite Bowenia and Stangeria in Stangeriaceae (Hill et al., 2003; Stevenson, 1992). These characters similar to both genera are vascularized stipules, amphivasal cotyledon bundles, leaflet traces coming from more than one rachis bundle, uneven production of cataphylls, ovules connected under the megasporophyll stalk, and purple sarcotesta. Although morphological trees group these two genera together, molecular data always show weak affinity of the two suggesting that these characters evolved independently from the two genera (Hill et al., 2003; Bogler and Francisco-Ortega, 2004). A study by Griffith et al. (2012) using combined DNA sequences, morphology and phenology data also did not show evidences of strong connection between these two genera. Bowenia formed a distinct clade second to Dioon within Zamiaceae whereas Stangeria was embedded in a clade with Ceratozamia, Zamia and Microcycas (Griffith et al., 2012). The results of our study suggest that Bowenia and Stangeria are indeed taxonomically distant from each other despite having similar morphological features and being placed previously in the same family Stangeriaceae. The topology obtained in our study therefore

Peer) reviewing PDF | (2019:09:40891:2:1:NEW 20 Nov 2019) 
359

360

361

362

363

364

365

366

367

368

369

370

371

372

373

374

375

376

377

378

379

380

381

382

383

384

385

386

387

388

389

390

391

392

393

394

395

396

397

398

399

400

401

402

403

supports the formal classification of only two families, Cycadaceae and Zamiaceae, within extant Cycadophyta (Christenhusz et al., 2011). The previous placement of Bowenia and Stangeria under the same family was in fact inaccurate (Gorelick et al., 2014; Salas-Leiva et al., 2014; Chaw et al., 2005; Bogler and Francisco-Ortega, 2004; Hill et al., 2003) based on molecular data.

Differences in chromosome number and karyotype were also linked to the phylogenetic separation of Bowenia $(2 \mathrm{n}=18)$ and Stangeria $(2 \mathrm{n}=16)$ (Rastogi and Ohri, 2019; Moretti, 1990). This also provides an explanation to the phylogenetic affinity of Stangeria to Ceratozamia as they had the most similar karyotypes in Cycadales both having 12 metacentric, two submetacentric and two telocentric chromosomes (Kokubugata et al., 2001). Mapping the distribution of 18S and 26S rDNA sites in the somatic chromosomes of both genera also revealed similar dispersed patterns (Kokubugata et al., 2002). In addition, mapping of 5S rDNA site is similarly situated at the interstitial region of two metacentric chromosomes. However in Ceratozamia, it was positioned proximal to the center, whereas in Stangeria, it was located near the distal end. This indicates that at least one paracentric inversion might have occurred in the past evolution of these two genera (Kokubugata et al., 2004).

Salas-Leiva et al. (2013) were not able to specify morphological synapomorphies that support the relation of Stangeria with Neotropical cycads, as well as Bowenia with Southern Hemisphere cycads. This led us to search for shared morphological characters that would unite Stangeria and Bowenia with their respective clades in our whole cpDNA tree. One similarity observed is the obscurity of veins in the leaflets of Bowenia and Southern Hemisphere cycads, whereas in the clade comprising Stangeria and Neotropical cycads, the veins tend to be more embossed. However, this needs further validation especially in some large genera such as Encephalartos and Zamia as they seem to exhibit more diversity in articulation of veins. Another shared characteristic is the type of stem wherein cycads can be divided into two categories. In Dioon, Stangeria, Ceratozamia, Zamia and Microcycas, the stem is monoxylic characterized by narrow cambiums with only one ring of secondary xylem and no apparent successive growth. Whereas in Bowenia, Encephalartos, Lepidozamia and Macrozamia, also including Cycas, the stem is polyxylic characterized by multiple layers of cortical cambiums and secondary thickening (Govil, 2014; Berry, 1918; Chamberlain, 1912). Moreover, Dehgan and Dehgan (1988) studied the pollen morphology within Cycadales and determined that Bowenia resembled a psilate exine surface and have relatively thin walls and similar alveolar arrangement with the pollen of all Southern Hemisphere cycads. On the other hand, Stangeria shares a foveolate exine surface and relatively thick walls with all Neotropical cycads. These characteristics can also be attributed to the pollination biology of Cycadales. Norstog (1987) hypothesized three pollination modes in cycads: anemophily (pollination by wind), entomophily (pollination by insects), and amphiphily (anemophily succeeded by entomophily). Although all genera are likely to be amphiphilous, taxa whose pollen surface lack ornamentation and walls are relatively thin (Macrozamia, Lepidozamia, Encephalartos, Bowenia) are presumably anemophilous as the smooth, non-sticky and thin surface makes the pollen easier to be dispersed by wind (Dehgan and Dehgan, 1988; Norstog, 1987; Thanikaimoni, 1986). On the contrary, cycads whose pollen surface consist of coarse pits and walls are relatively thick (Ceratozamia, Dioon, Microcycas, Stangeria, and Zamia) are probably entomophilous as the rough and thick surface seem to be more attuned to pollination by insects (Dehgan and Dehgan, 1988; Norstog, 1987; Tang, 1987; Punt, 1986). In addition, pollen grain morphology of Dioon and Stangeria were found to be highly similar having subcircular outline and foveolate exine surface. Aside from having a single vascular ring, both genera also has a 
404

405

406

407

408

409

410

411

412

413

414

415

416

417

418

419

420

421

422

423

424

425

426

427

428

429

430

431

432

433

434

435

436

437

438

439

440

441

442

443

444

445

446

447

448

449

common leaflike megasporophyll which was presumed to be a shared primitive feature that was conserved independently (Dehgan and Dehgan, 1988).

The African genera Encephalartos and Stangeria were separated into different clades suggesting that their evolutionary origin may have occurred before South American, African and Australian continents split (Hill et al., 2003) that accounts for their shared morphological and molecular features with other genera in Zamiaceae. The morphological similarities discussed in the previous section somehow provide biogeographical linkage between the African Stangeria and the cycads endemic to the Americas (Dioon, Ceratozamia, Microcycas and Zamia). In our hypothesis, the lack of diverse morphological synapomorphies to resolve taxonomic placements of Dioon, Stangeria and Bowenia might be due to the fact that only a number of extant cycads remain and the lack of these presumed extinct species are causing discrepancies in consolidating biogeographical, morphological and molecular phylogenies. Hence we place an emphasis on the hypothesis that around 200-135 MYA in Gondwana (Bogler and Francisco-Ortega, 2004; Jokat et al., 2003), the southern part of Pangaea where Africa, the Americas, Antarctica, India and Australia were once connected, there might exist other ancestral cycads species common between (1) DioonStangeria, (2) Stangeria-Ceratozamia, (3) Stangeria-Zamia-Microcycas, (4) Stangeria-Bowenia, and (5) Encephalartos-Lepidozamia-Macrozamia. To support this theory, the latter two would therefore require common ancestor/s situated in Antarctica wherein the shift in climate and environment after fragmentation of the land masses caused eventual extinction of the presumed cycad ancestors. This theory is very likely as cycad fossils from the genus Eostangeria was already discovered in North America and Europe, believed to have existed before the final division of Pangaea supercontinent (Uzunova et al., 2001; Kvacek and Manchester, 1999). A fossil cycad taxa, Restrepophyllum, was also discovered in Patagonia, Argentina and found to be morphologically similar to Zamia as well as few shared characters with Stangeria. This suggests a possible northward migration of Zamia from South America and that members of Zamiaceae and putative Stangeriaceae were widespread in Patagonia during the Early Cretaceous (Passalia et al., 2010). Other fossil cycad taxa include genera Dioonopsis found in Northeast Japan (Horiuchi and Kimura, 1987) and western North America (Erdei et al., 2012), Encephalartites (Takimoto and Ohana, 2015) in Northeast Japan, Crossozamia in Taiyuan, China (Gao and Thomas, 1989), Antarcticycas in Antarctica (Smoot et al., 1985) and Zamia fossil species discovered in Panama (Erdei et al., 2018). Most of these fossil discoveries were found to be morphologically linked to extant cycads under Zamiaceae, providing plausible explanations to the diverse morphological characters observed in Zamiaceae species compared to the more conserved characters in Cycadaceae. Phylogenetic studies were mostly restricted on extant cycads and these lost ancestors might be the missing links that could bridge the gap on the taxonomic issues of Dioon and the affinity of Stangeria and Bowenia with Neotropical cycads and Southern Hemisphere cycads, respectively, despite their differences in distribution and morphology. Only upon integration of extinct and extant cycads will we gain profound understanding on this intriguing group of plants.

\section{CONCLUSION}

The use of complete chloroplast genome proved to be advantageous in the phylogenetic reconstruction of Cycadales due to its conserved genomic structure and arrangement. Likewise, it holds sufficient genetic information to discriminate variation between species. Here, we present

Peer) reviewing PDF | (2019:09:40891:2:1:NEW 20 Nov 2019) 
450

451

452

453

454

455

456

457

458

459

460

461

462

463

464

465

466

467

468

469

470

471

472

473

474

475

476

477

478

479

480

481

482

483

484

485

486

487

488

the 165,688 bp sequence of the whole chloroplast genome of Microcycas calocoma which is within the range of all previously sequenced cycad genomes. The phylogenetic analysis of Cycadales confirmed that Microcycas is closely related to Zamia and sister to Ceratozamia, and that Stangeria and Bowenia are in different groups; thus stressing that their previous placement in a single family was definitely inappropriate. Hence, our resulting taxonomic classification using chloroplast genomes are consistent with all other molecular phylogenies of cycads (Salas-Leiva et al., 2013; Christenhusz et al., 2011; Bogler and Francisco-Ortega, 2004; Hill et al., 2003).

Furthermore, sequence variation analyses showed that all cycad genomes share highly similar genomic profiles confirming their slow evolution and reduced mutations in comparison with other gymnosperms and seed plants. No rearrangements in the genome structure were detected. This was expected as cycads are known to have a static evolutionary history, undergoing few changes in morphology since the Jurassic Period (Wu and Chaw, 2015; Nagalingum et al., 2011). However, the common identity profiles were shared less in the inverted repeat regions as well as non-coding sequence regions, suggesting their potential use as regions of interest in studying cycad evolution and phylogeny. In Zamiaceae, only a single species representing each genus has a completelysequenced chloroplast genome. Thus, adding more sequences to large genera, such as Zamia and Encephalartos, is crucial to validate existing phylogenetic data and to bridge knowledge gaps regarding cycads species divergence in land plant evolution. Furthermore, the need to expand our knowledge on the field of paleobotany, pollination biology and anatomical and morphological characterization of cycads opens up research opportunities to address incongruence between morphological and molecular phylogenies in Cycadales.

\section{Literature Cited}

Altschul, S.F., Gish, W., Miller, W., Myers, E.W. and Lipman, D.J. (1990). Basic local alignment search tool. Journal of Molecular Biology 215(3): 403-410.

Asaf, S., Khan, A.L., Khan, A.R., Waqas, M., Kang, S.M., Khan, M.A., Lee, S.M. and Lee, I.J. (2016). Complete chloroplast genome of Nicotiana otophora and its comparison with related species. Frontiers in Plant Science 7 (843): 1-12.

Ashburner, M., Ball, C.A., Blake, J.A., Botstein, D., Butler, H., Cherry, J.M., Davis, A.P., Dolinski, K., Dwight, S.S., Eppig, J.T., Harris, M.A., Hill, D.P., Issel-Tarver, L., Kasarskis, A., Lewis, S., Matese, J.C., Richardson, J.E., Ringwald, M., Rubin, G.M. and Sherlock G. (2000). Gene Ontology: Tool for the unification of biology. Nature Genetics 25(1): 25-29.

Berry, E.W. (1918). Paleobotany: A sketch of the origin and evolution of floras. In Walcott, C.D. Report of the Secretary of the Smithsonian Institution: 289-407.

Bogler, D.J. and Francisco-Ortega, J. (2004). Molecular systematic studies in cycads: Evidence from $t r n L$ intron and ITS2 rDNA sequences. The Botanical Review 70(2): 260-273.

Borgstrom, E., Lundin, S. and Lundeberg, J. (2011). Large scale library generation for high throughput sequencing. PLoS One 6: e19119.

Peer) reviewing PDF | (2019:09:40891:2:1:NEW 20 Nov 2019) 
489

490

491

492

493

494

495

496

497

498

499

500

501

502

503

504

505

506

507

508

509

510

511

512

513

514

515

516

517

518

519

520

521

522

523

524

Bösenberg, J.D. 2010. Microcycas calocoma. The IUCN Red List of Threatened Species 2010:

e.T42107A10647674. http://dx.doi.org/10.2305/IUCN.UK.20103.RLTS.T42107A10647674.en. Downloaded on 03 October 2019.

Brudno, M., Malde, S., Poliakov, A., Do, C.B., Couronne, O., Dubchak, I., and Batzoglou, S. (2003). Glocal Alignment: Finding Rearrangements During Alignment. Bioinformatics, 19S1: i54-i62.

Calonje, M., Stevenson, D.W. and Osborne, R. (2019). The World List of Cycads, online edition [Internet]. 2013-2019. [cited 2019 Oct 03]. Available from: http://www.cycadlist.org.

Chamberlain, C.J. (1912). Morphology of Ceratozamia. Botanical Gazette, 53 (1): 1-19.

Chaves, R. and Genaro, J.A. (2005). A new species of Pharaxonotha (Coleoptera: Erotylidae), probable pollinator of the endangered Cuban cycad, Microcycas calocoma (Zamiaceae). Insecta Mundi 19 (3): 143-150.

Chaw, S.M., Walter, T.W., Chang, C.C., Hu, S.H. and Chen, S.H. (2005). A phylogeny of cycads (Cycadales) inferred from chloroplast $m a t K$ gene, $\operatorname{trnK}$ intron, and nuclear rDNA ITS region. Molecular Phylogenetics and Evolution 37: 214-234.

Chaw, S.M., Parkinson, C.L., Cheng, Y., Vincent, T.M. and Palmer, J.D. (2000). Seed plant phylogeny inferred from all three plant genomes: Monophyly of extant gymnosperms and origin of Gnetales from conifers. PNAS 97 (8): 4086-4091.

Choi, K.S., Chung, M.G. and Park, S.J. (2016). The complete chloroplast genome sequences of three Veroniceae species (Plantaginaceae): Comparative analysis and highly divergent regions. Frontiers in Plant Science 7 (355): 1-8.

Christenhusz, M. J. M., Reveal, J. L., Farjon, A., Gardner, M. F., Mill, R. R., \& Chase, M. W. (2011). A new classification and linear sequence of extant gymnosperms. Phytotaxa, 19 (1): 55 .

Cronn, R., Liston, A., Parks, M., Gernandt, D.S. and Shen, R.K. (2008). Multiplex sequencing of plant chloroplast genomes using Solexa sequencing-by- synthesis technology. Nucleic Acids Research 36:e122.

Dehgan, B., Schutzman, B.A. and Almira,F. (1993). Utilization of scanning electron microscopy on the study of surface features in Cycadales. In: Stevenson DW, Norstog KJ. eds. The biology, structure and systematics of the Cycadales. Proceedings of the Second International Conference on Cycad Biology. Palm \& Cycad Societies of Australia, Milton, Queensland: 228-235.

Dehgan, B. and Dehgan, N.B. (1988). Comparative pollen morphology and taxonomic affinities in Cycadales. Amer. J. Bot. 75(10): 1501-1516.

De Luca, P., Moretti, A., Sabato, S. and Gigliano, G.S. (1982). A comparative study of cycad mucilages. Phytochemistry 21: 1609-1611. 
525

526

527

528

529

530

531

532

533

534

535

536

537

538

539

540

541

542

543

544

545

546

547

548

549

550

551

552

553

554

555

556

557

558

559
Dong, W., Xu, C., Cheng, T. and Zhou, S. (2013). Complete chloroplast genome of Sedum sarmentosum and chloroplast genome evolution in Saxifragales. PLoS ONE 8(10): e77965.

Erdei, B., Manchester, S. R., and Kvaček, Z. (2012). Dioonopsis Horiuchi et kimura leaves from the Eocene of western North America: A cycad shared with the Paleogene of Japan. International Journal of Plant Sciences, 173 (1): 81-95.

Erdei, B., Calonje, M., Hendy, A. and Espinosa, N. (2018). A review of the Cenozoic fossil record of the genus Zamia L. (Zamiaceae, Cycadales) with recognition of a new species from the late Eocene of Panama - evolution and biogeographic inferences. Bulletin of Geosciences 93 (2): 185-204.

Feng, Z., Lv, Y., Guo, Y., Wei, H.B. and Kerp, H. (2017). Leaf anatomy of a late Palaeozoic cycad. Biol. Lett. 13: 20170456.

Frazer KA, Pachter L, Poliakov A, Rubin EM, Dubchak I. (2004). VISTA: computational tools for comparative genomics. Nucleic Acids Res. 32 (Web Server issue):W273-9.

Gao, Z.F., and Thomas, B. A. (1989). A review of fossil cycad megasporophylls, with new evidence of Crossozamia Pomel and its associated leaves from the lower Permian of Taiyuan, China. Review of Palaeobotany and Palynology, 60(3-4), 205-223.

Gorelick, R., Fraser, D., Zonneveld, B.J.M. and Little, D.P. (2014). Cycad (Cycadales) chromosome numbers are not correlated with genome size. International Journal of Plant Sciences 175 (9): 986-997.

Govil, C.M. (2014). Gymnosperms: Extinct and extant. India: Krishan Prakashan.

Griffith, M.P., Calonje, M.A., Stevenson, D.W., Husby, C.E. and Little, D.P. (2012). Time, place, and relationships: cycad phenology in a phylogenetic and biogeographic context. Memoirs of the New York Botanical Garden 106: 59-81.

Guo, W., Grewe, F., Cobo-Clark, A., Fan, W., Duan, Z., Adams, R.P., Schwarzbach. A.E., and Mower, J.P. (2014). Predominant and substoichiometric isomers of the plastid genome coexist within Juniperus plants and have shifted multiple times during cupressophyte evolution. Genome Biol Evol 6: 580-590.

Hill, K.D., Chase, M.W., Stevenson, D.W., Hills, H.G. and Schutzman, B. (2003). The families and genera of cycads: A molecular phylogenetic analysis of Cycadophyta based on nuclear and plastid DNA sequences. International Journal of Plant Sciences 164: 944-948.

Hong, S.Y., Cheon, K.S., Yoo, K.O., Lee, H.O., Cho, K.S., Suh, J.T., Kim, S.J., Nam, J.H., Sohn, H.B. and Kim, Y.H. (2017). Complete chloroplast genome sequences and comparative analysis of Chenopodium quinoa and C. album. Frontiers in Plant Science 8 (1696): 1-12.

Horiuchi, J. and Kimura, T. (1987). Dioonopsis nipponica gen. et. sp. nov., a new cycad from the palaeogene of Japan. Review of Palaeobotany and Palynology, 51(1-3), 213-225.

Peer) reviewing PDF | (2019:09:40891:2:1:NEW 20 Nov 2019) 
560

561

562

563

564

565

566

567

568

569

570

571

572

573

574

575

576

577

578

579

580

581

582

583

584

585

586

587

588

589

590

591

592

593

Jiang, G.F., Hinsinger, D.D. and Strijk, J.S. (2016). Comparison of intraspecific, interspecific and intergeneric chloroplast diversity in Cycads. Scientific Reports 6: 31473.

Jokat, W., Boebel, T., König, M. and Meyer, U. (2003). "Timing and geometry of early Gondwana breakup". Journal of Geophysical Research: Solid Earth. 108 (B9): 2428.

Kanehisa, M., Goto, S., Kawashima, S., Okuno Y and Hattori M. (2004). The KEGG resource for deciphering the genome. Nucleic Acids Research 32: D277-D280.

Kanehisa, M. (1997). A database for post-genome analysis. Trends in genetics 13(9): 375.

Kanehisa, M., Goto, S., Hattori, M., Aoki-Kinoshita, K.F., Itoh, M., Kawashima, S., Katayama, T., Araki, M. and Hirakawa, M. (2006). From genomics to chemical genomics: New developments in KEGG. Nucleic Acids Research 34: D354-D357.

Kokubugata, G., Vovides, A.P. and Kondo, K. (2004). Mapping 5S ribosomal DNA on somatic chromosomes of four species of Ceratozamia and Stangeria eriopus (Cycadales). Botanical Journal of the Linnean Society 145: 499-504.

Kokubugata G, Hill KD and Kondo K. (2002). Ribosomal DNA distribution in somatic chromosomes of Stangeria eriopus (Stangeriaceae, Cycadales) and molecularcytotaxonomical relationships to the other cycad genera. Brittonia 54: 1-5.

Kokubugata G, Hill KD, Wilson GW, Kondo K, Randall LM. (2001). A comparison of chromosome number and karyotype in somatic chromosomes of Bowenia and Stangeria (Stangeriaceae, Cycadales). Edinburgh Journal of Botany 58: 475-481.

Kvacek, Z. and Manchester, S.R. (1999). Eostangeria Barthel (extinct Cycadales) from the Paleogene of Western North America and Europe. Int. J. Plant Sci. 160 (3):621-629.

Lee, S.B., Kaittanis, C., Jansen, R.K., Hostetler, J.B., Tallon, L.J., Town, C.D. and Daniell, H. (2006). The complete chloroplast genome sequence of Gossypium hirsutum: Organization and phylogenetic relationships to other angiosperms. BMC Genomics 7 (61): 1-12.

Li, R., Zhu, H., Ruan, J., Qian, W., Fang, X., Shi, Z., Li, Y., Li, S., Shan, G., Kristiansen, K.,Li, S., Yang, H., Wang, J. and Wang, J. (2010). De novo assembly of human genomes with massively parallel short read sequencing. Genome Research 20:265-272.

Liu, L.X., Li, R., Worth, J.R.P., Li, X., Li, P., Cameron, K.M. and Fu, C.X. (2017). The complete chloroplast genome of chinese bayberry (Morella rubra, Myricaceae): Implications for Understanding the Evolution of Fagales. Frontiers in Plant Science 8 (968): 1-15.

Liu, J., Zhang, S., Nagalingum, N.S., Chiang, Y.C., Lindstrom, A. and Gong, X. (2018). Phylogeny of the gymnosperm genus Cycas L. (Cycadaceae) as inferred from plastid and nuclear loci based on large-scale sampling: Evolutionary relationships and taxonomical implications. Molecular Phylogenetics and Evolution. 127: 87-97. 
594

595

596

597

598

599

600

601

602

603

604

605

606

607

608

609

610

611

612

613

614

615

616

617

618

619

620

621

622

623

624

625

626

627

628

629

Lodish, H., Berk, A., Zipursky, S.L., Matsudaira, P., Baltimore, D. and Darnell, J. (2000). Molecular Cell Biology. 4th edition. New York: W. H. Freeman. Section 9.7, Organelle DNAs. Available from: https:/www.ncbi.nlm.nih.gov/books/NBK21574/.

Lohse, M., Drechsel, O. and Bock, R. (2007). OrganellarGenomeDRAW (OGDRAW): A tool for the easy generation of high-quality custom graphical maps of plastid and mitochondrial genomes. Current Genetics 52: 267-274.

Lu, Y., Ran, J.H., Guo, D.M., Yang, Z.Y. and Wang, X.Q. (2014). Phylogeny and divergence times of gymnosperms inferred from single-copy nuclear genes. PLoS ONE 9: e107679.

Magrane, M. (2011). UniProt Knowledgebase: A hub of integrated protein data. Database: The Journal of Biological Databases \& Curation 9.

Mankga, L.T. and Yessoufou, K. (2017). Factors driving the global decline of cycad diversity. AoB Plants, 9 (4): plx022.

Martin, W., Deusch, O., Stawski, N., Grunheit, N. and Goremykin, V. (2005). Chloroplast genome phylogenetics: Why we need independent approaches to plant molecular evolution. Trends in Plant Science 10 (5): 1360-1385.

Mayor C., Brudno M., Schwartz J. R., Poliakov A., Rubin E. M., Frazer K. A., Pachter L. S. and Dubchak I. (2000). VISTA: Visualizing Global DNA Sequence Alignments of Arbitrary Length. Bioinformatics, 16:1046.

McPherson, H., van der Merwe, M., Delaney, S.K., Edwards, M.A., Henry, R.J., McIntosh, E., et al. (2013). Capturing chloroplast variation for molecular ecology studies: a simple next generation sequencing approach applied to a rainforest tree. BMC Ecol. 13: 8 .

Miller, M.A., Pfeiffer, W., and Schwartz, T. (2010) "Creating the CIPRES Science Gateway for inference of large phylogenetic trees" in Proceedings of the Gateway Computing Environments Workshop (GCE), 14 Nov. 2010, New Orleans, LA pp 1 - 8.

Moretti, A. (1990). Karyotype data on North and Central American Zamiaceae (Cycadales) and their phylogenetic implications. Am J Bot. 77:1016-29.

Nagalingum, N.S., Marshall, C.R., Quental, T.B., Rai, H.S., Little, D.P. and Mathews, S. (2011). Recent synchronous radiation of a living fossil. Science 334 (6057): 796-799.

Norstog, K. (1987). Cycads and the origin of insect pollination. Amer. Sci. 75: 270-279.

Passalia, M.G., Del Fueyo, G. and Archangelsky, S. (2010). An Early Cretaceous zamiaceous cycad of South West Gondwana: Restrepophyllum nov. gen. from Patagonia, Argentina. Review of Palaeobotany and Palynology 161: 137-150.

Pinares, A., Gonzalez-Astorga, J., Vovides, A.P., Lazcano, J. and Vendrame, W.A. (2009). Genetic diversity of the endangered endemic Microcycas calocoma (Miq.) A. DC (Zamiaceae, Cycadales): Implications for conservation. Biochemical Systematics and Ecology 37: 385-394.

Peer) reviewing PDF | (2019:09:40891:2:1:NEW 20 Nov 2019) 
630

631

632

633

634

635

636

637

638

639

640

641

642

643

644

645

646

647

648

649

650

651

652

653

654

655

656

657

658

659

660

661

662

663

664

665

Punt, W. (1986). Functional factors influencing pollen form. In S. Blackmore and I. K. Ferguson [eds.], Pollen and spores: form and function, 97-101. Academic Press, Orlando, FL. Rastogi, S. and Ohri, D. (2019). Karyotype evolution in cycads. Nucleus: 1-11.

Ronquist, F. and Huelsenbeck, J.P. (2003). MRBAYES 3: Bayesian phylogenetic inference under mixed models. Bioinformatics 19:1572-1574.

Salas-Leiva, D.E., Meerow, A.W., Calonje, M., Griffith, M.P., Francisco-Ortega, J. Nakamura, K., Stevenson, D.W., Lewis, C.E. and Namoff, S. (2013). Phylogeny of cycads based on multiple single-copy nuclear genes: Congruence of concatenated parsimony, likelihood and species tree inference methods. Annals of Botany 112: 1263-1278.

Shaw, J., Lickey, E.B., Schilling, E.E. and Small, R.L. (2007). Comparison of whole chloroplast genome sequences to choose noncoding regions for phylogenetic studies in angiosperms: The tortoise and the hare III. American Journal of Botany 94(3): 275-288.

Smith, D.R. (2017). Does cell size impact chloroplast genome size? Frontiers in Plant Science 8 (2116): 1-6.

Smoot, E. L., Taylor, T. N., \& Delevoryas, T. (1985). Structurally preserved fossil plants from Antarctica. I. Antarcticycas, gen. nov., a Triassic cycad stem from the Beardmore Glacier Area. American Journal of Botany, 72 (9): 1410.

Stamatakis A. (2014). RAxML version 8: a tool for phylogenetic analysis and post-analysis of large phylogenies. Bioinformatics 30 (9):1312-1313.

Stevenson, D.W. (1981). Observations on ptyxis, phenology, and trichomes in the Cycadales and their systematic implications. Am J Bot 68: 1104-1114.

Stevenson, D.W. (1990). Morphology and systematics of the Cycadales. Memoirs of the New York Botanical Garden 57: 8-55.

Stevenson, D.W. (1992). A formal classification of the extant cycads. Brittonia 44: 220-223.

Stevenson, D.W., A. Vovides, and J. Chemnick. 2003. Regional Overview: New World. pp. 3138. In Donaldson, J. S. [ed.]. Cycads. Status Survey and Conservation Action Plan. IUCN/SSC Cycad Specialist Group. IUCN, Gland, Switzerland and Cambridge, UK.

Takimoto, H. and Ohana, T. (2016). Encephalartites nipponensis sp. nov., from the Jurassic Tochikubo Formation (Oxfordian), Somanakamura Group, Northeast Japan. Paleontological Research 20 (3): 261-267.

Tatusov, R.L., Koonin, E.V. and Lipman, D.J. (1997).A genomic perspective on protein families. Science 278(5338): 631-637.

Tatusov, R.L., Fedorova, N.D., Jackson, J.D., Jacobs AR, Kiryutin B, Koonin EV, Krylov DM, Mazumder R, Mekhedov SL, Nikolskaya AN, Rao BS, Smirnov S, Sverdlov AV, Vasudevan S, Wolf YI, Yin JJ and Natale DA. (2003). The COG database: An updated version includes eukaryotes. BMC Bioinformatics 4 (1): 41.

Peer) reviewing PDF | (2019:09:40891:2:1:NEW 20 Nov 2019) 
666 Thanikaimoni, G. (1986). Pollen apertures: form and function. In S. Blackmore and I. K. Ferguson

667 [eds.], Pollen and spores: form and function, 119-136. Academic Press, Orlando, FL.

668

669

670

671

672

673

674

675

676

677

678

679

680

681

682

683

684

685

686

687

688

689

IUCN 2019. The IUCN Red List of Threatened Species. Version 2019-2. https://www.iucnredlist.org. Downloaded on 03 October 2019.

Uzunova, K., Palamarev, E. and Kvacek, Z. (2001). Eostangeria ruzinciniana (Zamiaceae) from the Middle Miocene of Bulgaria and its relationship to similar taxa of fossil Eostangeria, and extant Chigua and Stangeria (Cycadales). Acta Palaeobot. 41 (2): 177-193.

Wu, C.S. and Chaw, S.M. (2015).Evolutionary stasis in cycad plastomes and the first case of plastome GC-biased gene conversion. Genome Biology and Evolution 7(7): 2000-2009.

Wu, C.S., Wang, Y.N., Liu, S.M. and Chaw, S.M. (2007). Chloroplast genome (cpDNA) of Cycas taitungensis and $56 \mathrm{cp}$ protein-coding genes of Gnetum parvifolium: Insights into cpDNA evolution and phylogeny of extant seed plants. Molecular Biology and Evolution 24(6):1366-1379.

Wyman, S.K., Jansen, R.K. and Boore, J.L. (2004).Automatic annotation of organellar genomes with DOGMA. Bioinformatics 20: 3252-3255.

Xiao, L.Q. and Moller, M. (2015). Nuclear ribosomal ITS functional paralogs resolve the phylogenetic relationships of a late-miocene radiation Cycad Cycas (Cycadaceae). PLoS ONE 10(1): e0117971.

Yang, J.B., Tang, M., Li, H.T., Zhang, Z.R. and Li, D.Z. (2013). Complete chloroplast genome of the genus Cymbidium: Lights into the species identification, phylogenetic implications and population genetic analyses. BMC Evolutionary Biology 13 (84): 1-12.

Zhong, Z.-R., Li, N., Qian, D., Jin, J.-H., \& Chen, T. (2011). Maternal inheritance of plastids and mitochondria in Cycas L. (Cycadaceae). Molecular Genetics and Genomics, 286(5-6), 411-416. 
Table $\mathbf{1}$ (on next page)

Genes annotated in Microcycas calocoma

TABLE 1. List of genes encoded by Microcycas calocoma. 
1 TABLE 1. List of genes encoded by Microcycas calocoma.

\begin{tabular}{|c|c|}
\hline Gene category & Gene names \\
\hline ATP Synthase & $a t p \mathrm{~A}, a t p \mathrm{~B}, a t p \mathrm{E}, a t p \mathrm{~F}, a t p \mathrm{H}, a t p \mathrm{I}$ \\
\hline NADH dehydrogenase & $\begin{array}{l}n d h \mathrm{~A}, n d h \mathrm{~B}^{(\mathrm{x} 2)}, n d h \mathrm{C}, n d h \mathrm{D}, n d h \mathrm{E}, n d h \mathrm{~F}, n d h \mathrm{G}, n d h \mathrm{H}, n d h \mathrm{I}, \\
n d h \mathrm{~J}, n d h \mathrm{~K}\end{array}$ \\
\hline $\begin{array}{l}\text { Cytochrome b/f } \\
\text { complex }\end{array}$ & $\operatorname{pet} \mathrm{A}, \operatorname{pet} \mathrm{B}, \operatorname{pet} \mathrm{\textrm {D }}, \operatorname{pet} \mathrm{\textrm {G }}, \operatorname{pet} \mathrm{L}, \operatorname{pet} \mathrm{N}$ \\
\hline Photosystem I & $p s a \mathrm{~A}, p s a \mathrm{~B}, p s a \mathrm{C}, p s a \mathrm{I}, p s a \mathrm{~J}$ \\
\hline Photosystem II & $\begin{array}{l}p s b \mathrm{~A}, p s b \mathrm{~B}, p s b \mathrm{C}, p s b \mathrm{D}, p s b \mathrm{E}, p s b \mathrm{~F}, p s b \mathrm{H}, p s b \mathrm{I}, p s b \mathrm{~J}, p s b \mathrm{~K}, \\
p s b \mathrm{~L}, p s b \mathrm{M}, p s b \mathrm{~N}, p s b \mathrm{~T}, p s b \mathrm{Z}\end{array}$ \\
\hline RubisCO large subunit & $r b c \mathrm{~L}$ \\
\hline $\begin{array}{l}\text { Ribosomal protein } \\
\text { genes (large subunits) }\end{array}$ & rpl14, rpl16, rpl2, rpl20, rpl22, rpl23, rpl32, rpl33, rpl36 \\
\hline $\begin{array}{l}\text { Ribosomal protein } \\
\text { genes (small subunits) }\end{array}$ & $\begin{array}{l}r p s 11, r p s 12^{(\times 3)}, r p s 14, r p s 15, r p s 16, r p s 18, r p s 19, r p s 2, r p s 3 \\
r p s 4, r p s 7^{(\times 2)}, r p s 7, r p s 8\end{array}$ \\
\hline RNA Polymerase & rpoA, rpoB, rpo $1, r p o \mathrm{C} 2$ \\
\hline Ribosomal RNA genes & $r r n 16^{(\mathrm{x} 2)}, r r n 23^{(\mathrm{x} 2)}, \operatorname{rrn} 4 .^{(\mathrm{x} 2)}, r r n 5^{(\mathrm{x} 2)}$ \\
\hline Transfer RNA genes & 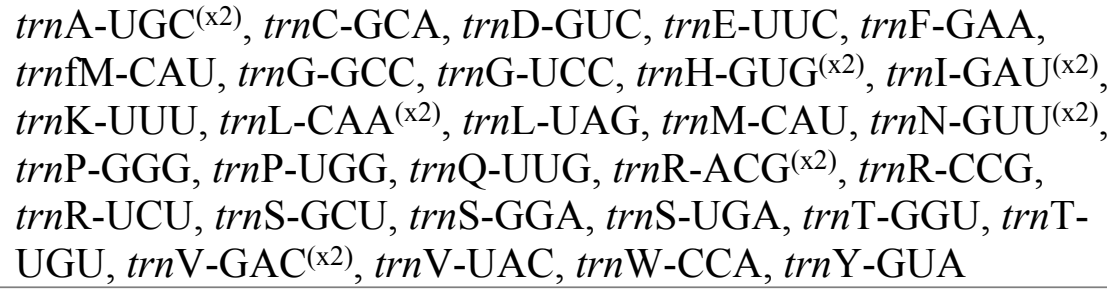 \\
\hline $\begin{array}{l}\text { ATP-dependent } \\
\text { protease }\end{array}$ & clpP \\
\hline Maturase & matK \\
\hline $\begin{array}{l}\text { Hypothetical } \\
\text { chloroplast reading } \\
\text { frames }\end{array}$ & $y c f 1, y c f 12, y c f 2^{(\mathrm{x} 2)}, y c f 3, y c f 4$ \\
\hline Acetyl-CoA carboxylase & $\operatorname{accD}$ \\
\hline $\begin{array}{l}\text { C-type cytochrome } \\
\text { synthesis gene }\end{array}$ & $\operatorname{ccs} \mathrm{A}$ \\
\hline $\begin{array}{l}\text { Envelope membrane } \\
\text { protein }\end{array}$ & $\operatorname{cem} \mathrm{A}$ \\
\hline $\begin{array}{l}\text { Photochlorophyllide } \\
\text { reductase }\end{array}$ & $\operatorname{chl} l \mathrm{~B}, \operatorname{chl} l \mathrm{~L}, \operatorname{chl} \mathrm{N}$ \\
\hline $\begin{array}{l}\text { Translational initiation } \\
\text { factor }\end{array}$ & $\operatorname{infA}$ \\
\hline
\end{tabular}




\section{Table 2 (on next page)}

Gene features of Microcycas calocoma

TABLE 2. Characteristics of complete chloroplast genomes of Cycadales showing genome lengths, gene numbers and GC content. Data are retrieved from GenBank and accession numbers are indicated. 
1 TABLE 2. Characteristics of complete chloroplast genomes of Cycadales showing genome lengths, gene 2 numbers and GC content. Data are retrieved from GenBank and accession numbers are indicated.

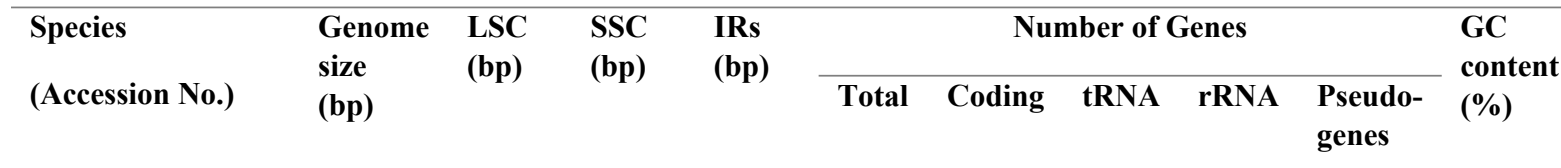

\begin{tabular}{llllllllllll}
\hline $\begin{array}{l}\text { Microcycas } \\
\text { calocoma }\end{array}$ & 165,688 & 90,651 & 22,741 & 26,148 & 134 & 86 & 39 & 8 & 1 & 39.6
\end{tabular}

(MN577566)

\begin{tabular}{ccccccccccc}
\hline Cycas revoluta & 162,489 & 88,977 & 23,376 & 25,068 & 157 & 109 & 39 & 8 & 1 & 39.4 \\
(NC_020319.1) & & & & & & & & & &
\end{tabular}

\begin{tabular}{ccccccccccc}
\hline Cycas debaoensis & 162,094 & 88,852 & 23,088 & 25,076 & 133 & 87 & 37 & 8 & 1 & 39.4 \\
(KM459003) & & & & & & & & & &
\end{tabular}

\begin{tabular}{|c|c|c|c|c|c|c|c|c|c|c|}
\hline $\begin{array}{c}\text { Cycas debaoensis } \\
\text { (KU743927) }\end{array}$ & 162,092 & 88,854 & 23,088 & 25,076 & 133 & 87 & 37 & 8 & 1 & 39.4 \\
\hline $\begin{array}{r}\text { Cycas taitungensis } \\
\text { (NC_009618.1) }\end{array}$ & 163,403 & 90,216 & 23,039 & 25,074 & 169 & 122 & 38 & 8 & 1 & 39.5 \\
\hline $\begin{array}{l}\text { Cycas } \\
\text { panzhihuaensis } \\
\qquad \text { (NC_031413.1) }\end{array}$ & 162,470 & 88,932 & 23,488 & 25,045 & 157 & 109 & 39 & 8 & 1 & 39.4 \\
\hline $\begin{array}{l}\text { Stangeria eriopus } \\
\text { (NC_026041.1) }\end{array}$ & 163,548 & 89,850 & 23,006 & 25,346 & 134 & 81 & 39 & 8 & 6 & 39.5 \\
\hline $\begin{array}{r}\text { Bowenia serrulata } \\
\text { (NC_026036.1) }\end{array}$ & 165,695 & 90,733 & 23,156 & 25,903 & 134 & 87 & 38 & 8 & 1 & 39.9 \\
\hline $\begin{array}{r}\text { Dioon spinolosum } \\
\text { (NC_027512.1) }\end{array}$ & 161,815 & 88,756 & 23,355 & 24,852 & 135 & 87 & 39 & 8 & 1 & 40.1 \\
\hline $\begin{array}{l}\text { Encephalartos } \\
\text { lehmannii }\end{array}$ & 165,822 & 90,724 & 23,302 & 25,898 & 135 & 87 & 39 & 8 & 1 & 39.9 \\
\hline
\end{tabular}

(NC_027514.1)

\begin{tabular}{llllllllllll}
\hline $\begin{array}{l}\text { Macrozamia } \\
\text { mountperriensis }\end{array}$ & 166,341 & 91,171 & 23,334 & 25,918 & 135 & 87 & 39 & 8 & 1 & 39.8 \\
\end{tabular}

(NC_027511.1)

\begin{tabular}{|c|c|c|c|c|c|c|c|c|c|c|}
\hline $\begin{array}{l}\begin{array}{l}\text { Lepidozamia } \\
\text { peroffskyana }\end{array} \\
\qquad \text { (NC_027513.1) }\end{array}$ & 165,939 & 90,804 & 23,299 & 25,918 & 135 & 87 & 39 & 8 & 1 & 39.9 \\
\hline $\begin{array}{l}\text { Ceratozamia hildae } \\
\qquad \text { (NC_026037.1) }\end{array}$ & 165,733 & 90,487 & 22,973 & 26,137 & 135 & 87 & 39 & 8 & 1 & 39.7 \\
\hline
\end{tabular}




\begin{tabular}{ccccccccccc}
\hline Zamia furfuracea & 164,953 & 90,441 & 23,228 & 25,642 & 135 & 87 & 39 & 8 & 1 & 39.7 \\
(NC_026040.1) & & & & & & & & & &
\end{tabular}

3 
Figure 1

Microcycas calocoma annotated circular genome

FIGURE 1. Gene map of Microcycas calocoma whole chloroplast genome. Innermost circle indicates partition of large single copy (LSC) region, small single copy (SSC) region and 2 regions of inverted repeats $\left(I R_{A}\right.$ and $\left.I R_{B}\right)$ which are also highlighted by the thick lines found in the outermost circle. Genes within the outermost circle are transcribed in clockwise direction whereas genes on the outside are transcribed in counter clockwise direction. Colors denote the different functions of genes. 


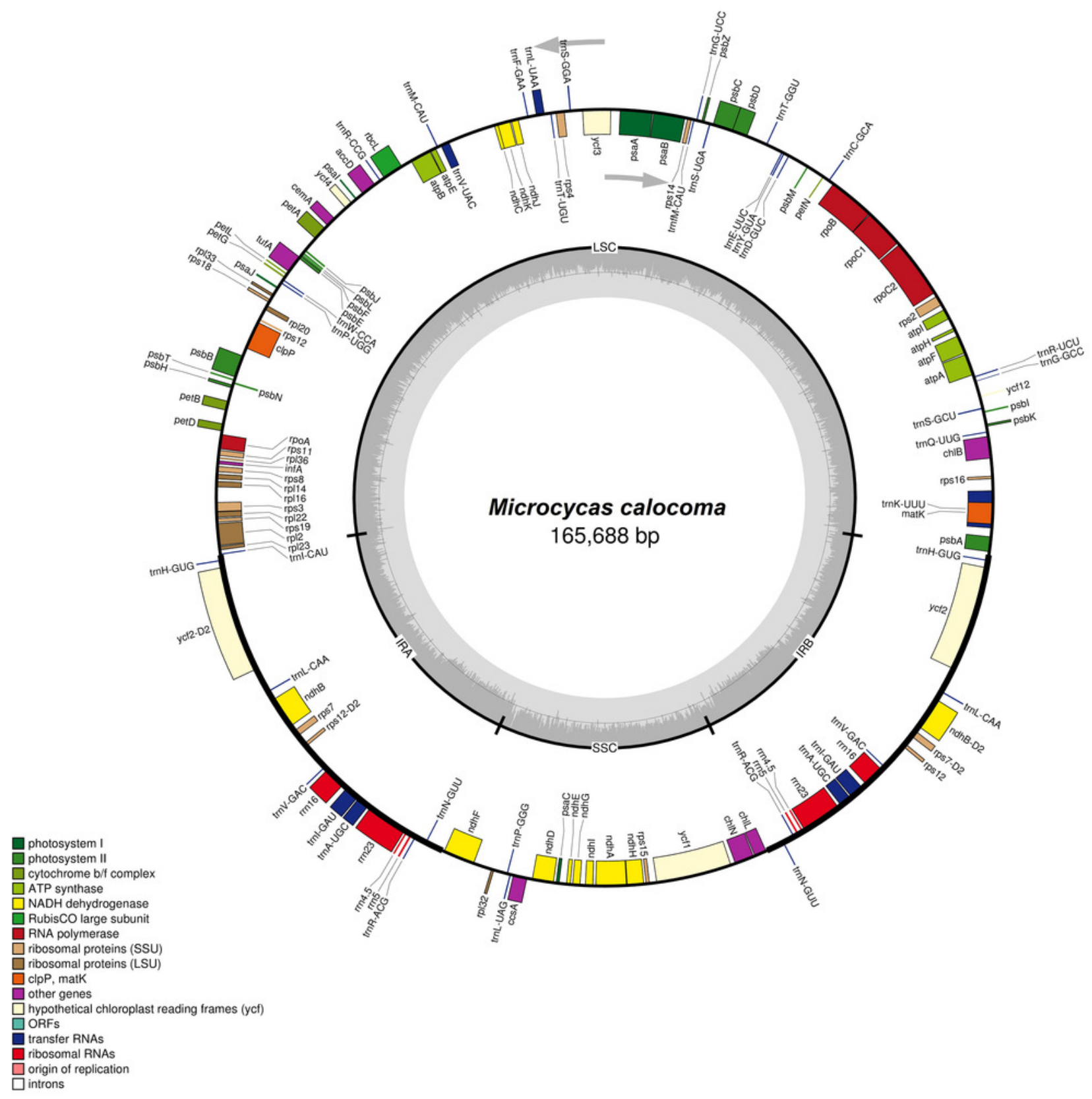


Figure 2

Sequence identity plots of various genera in Cycadales using mVISTA

FIGURE 2. Sequence variations among 10 genera in Cycadales using $C$. debaoensis as base reference. Complete chloroplast genomes generated by mVISTA. Regions in pink indicate conserved non-coding sequences, purple are conserved exons, while white-colored regions identify more variable sites. The $y$-axis represents percent identity ranging from 50 to $100 \%$. IR junctions are indicated in parentheses to show LSC, SSC and IR regions. 


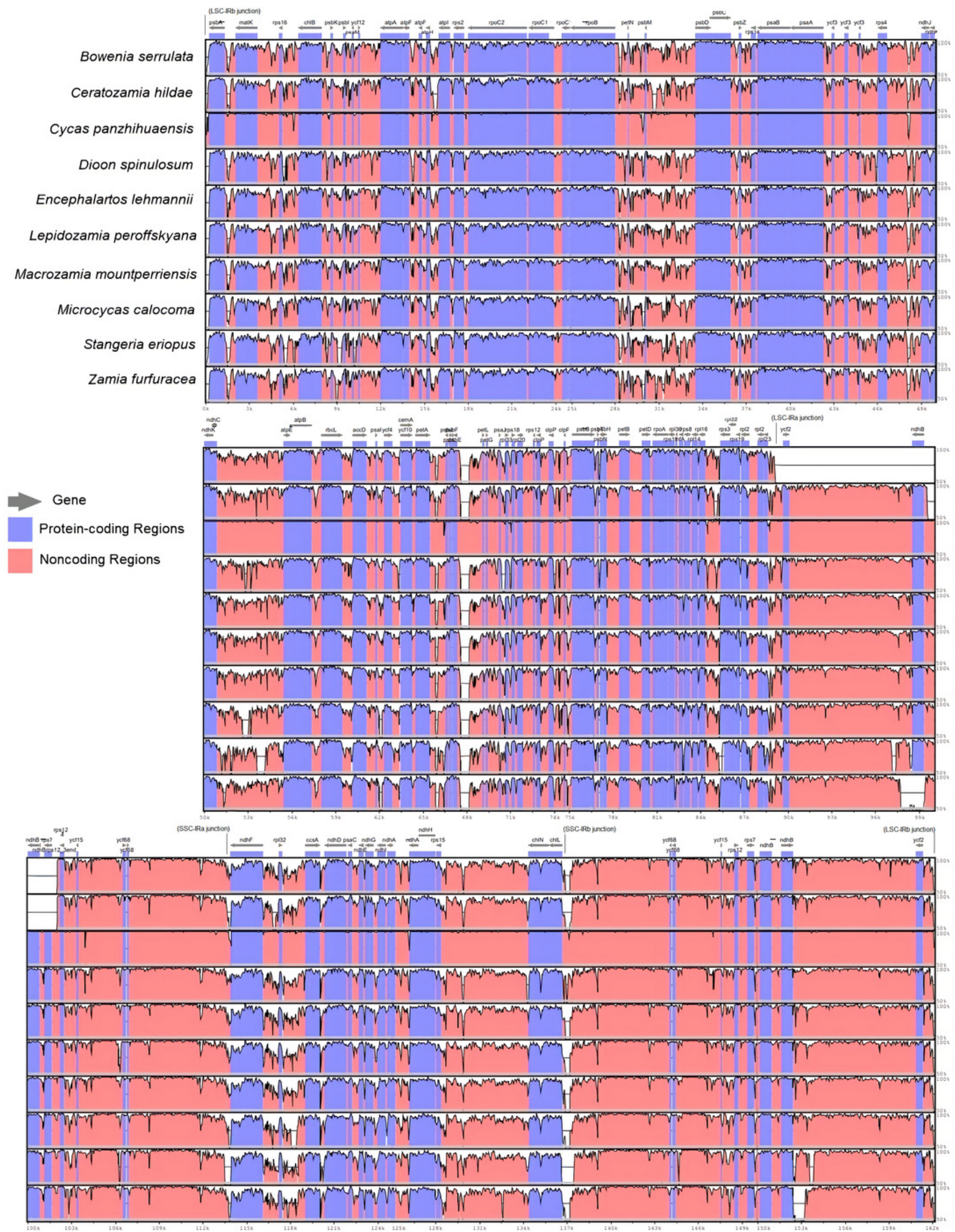


Figure 3

cpDNA tree obtained using $M L$ and $B \mathrm{I}$

FIGURE 3. Maximum likelihood (ML) tree and Bayesian inference (BI) tree of concatenated data matrix of 81 protein-coding genes from complete chloroplast genome sequences of 10 genera of Cycadales available in GenBank. Ginkgo biloba was used as outgroup. Bootstrap support values are given at the nodes annotated as ML/BI. Branches with bootstrap values > 75 for ML and Bayesian posterior probabilities > 0.95 for BI were considered as highly supported.

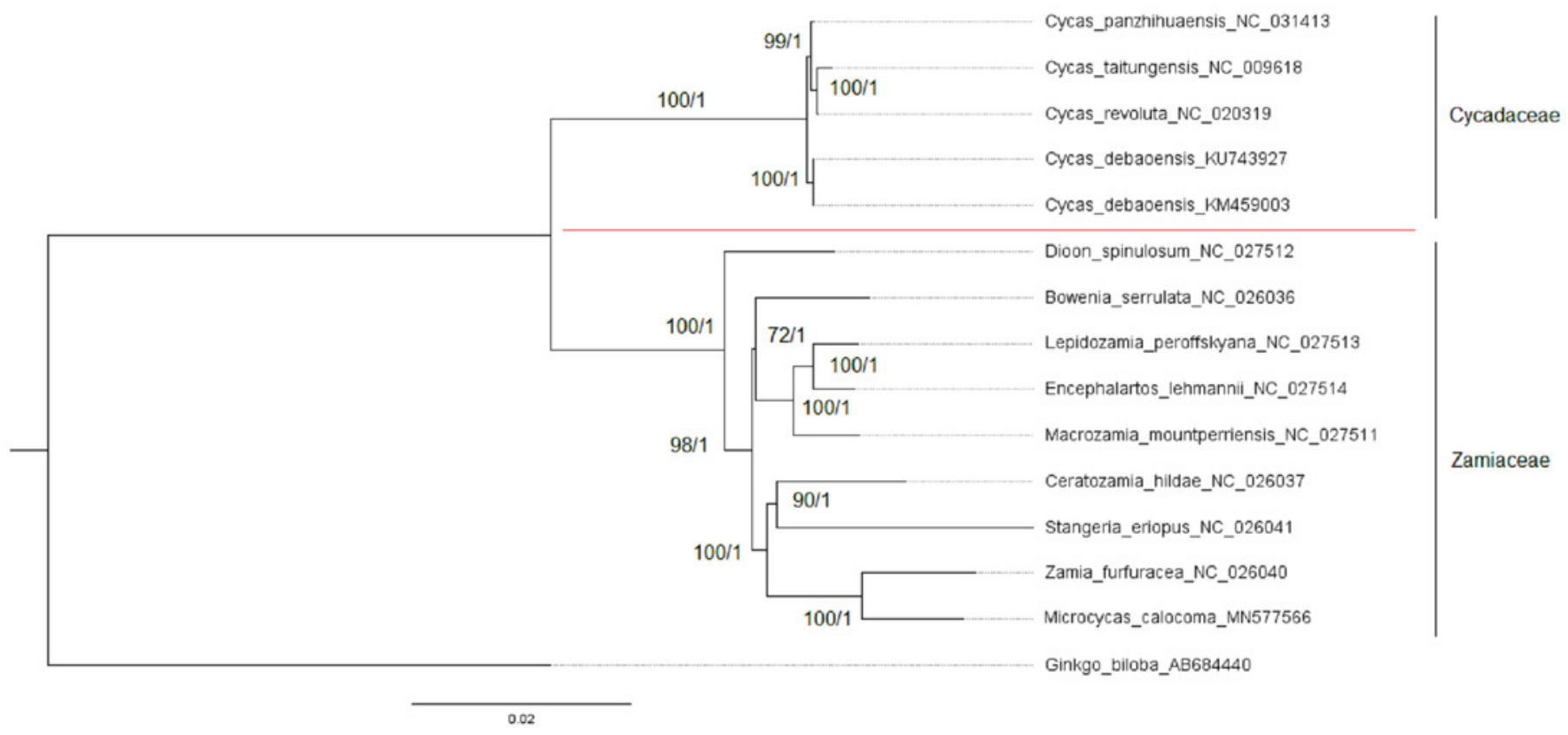

